https://www.journal-imab-bg.org

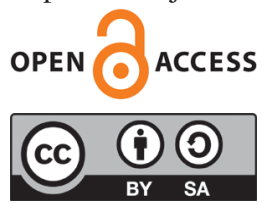

Case report

\title{
CONTACT DERMATITIS FROM PLASTICINE AND SLIME IN A 9-YEAR-OLD CHILD
}

\author{
Klimentina Gospodinova ${ }^{1}$, Ivelina Yordanova ${ }^{1}$, Dimitar Gospodinov ${ }^{1}$, Jana \\ Kazandjieva $^{2}$ \\ 1) Department of Dermatology, Venereology and Allergology, Medical \\ University, Pleven, Bulgaria \\ 2) Department of Dermatology and Venereology, Medical University, Sofia, \\ Bulgaria.
}

\begin{abstract}
Contact dermatitis is an acute or chronic inflammatory reaction in response to substances coming into contact with the skin. Differentiating between irritant contact dermatitis and allergic contact dermatitis in practice, as well as finding the exact causative agent from the environment, often pose a challenge to the clinician. We present a case of contact dermatitis in a 9-year-old child caused by modeling clay (plasticine) and slime. The treatment with local corticosteroids and emollients and the discontinuation of contact with the identified insulting agents lead to a goodherapeutic result.
\end{abstract}

Keywords: irritant contact dermatitis, allergic contact dermatitis, modeling clay, slime,

\section{INTRODUCTION}

Contact dermatitis (CD) is defined as an inflammatory reaction in response to substances that come in contact with the skin. Irritant contact dermatitis (ICD) is caused by an external agent acting as a chemical or physical substance, causing a non-allergic inflammatory response. In allergic contact dermatitis (ACD), the external agent acts as a hapten, binds to the epidermal proteins and becomes an allergen, thus leading to a classic, delayed T-cell mediated hypersensitivity response. Clinical findings of acute $\mathrm{CD}$ include erythema, edema, and vesiculation, and of chronic CD - xerosis, lichenification, hyperkeratosis, and rhagades accompanied by severe itching [1].

\section{CLINICAL CASE}

A 9-year-old girl was referred to the dermatological clinic with an itchy rash and swelling in the area of both palms, as well as changes in the nails, with a 4-month prescription. Complaints appeared after a contact with plasticine and slime, which the child made alone by mixing colored dust with a special solution. A child's favorite game was to create artificial nails from plasticine, which she used to put on her fingernails. The changes on the skin of the palms and nails persisted despite treatment with topical corticosteroids and antibiotics. The child is burdened by the paternal line for atopy. There are no data on concomitant diseases. The physical examination revealed erythema and edema on the palms and fingers and pulpitis with single fissures on the fingertips. (fig. 1) Fingernails were onychodystrophic, with lack of eponychium and longitudinal striation. (fig. 2)

Fig. 1. Erythema and edema of the palm, pulpitis of the volar fingertips

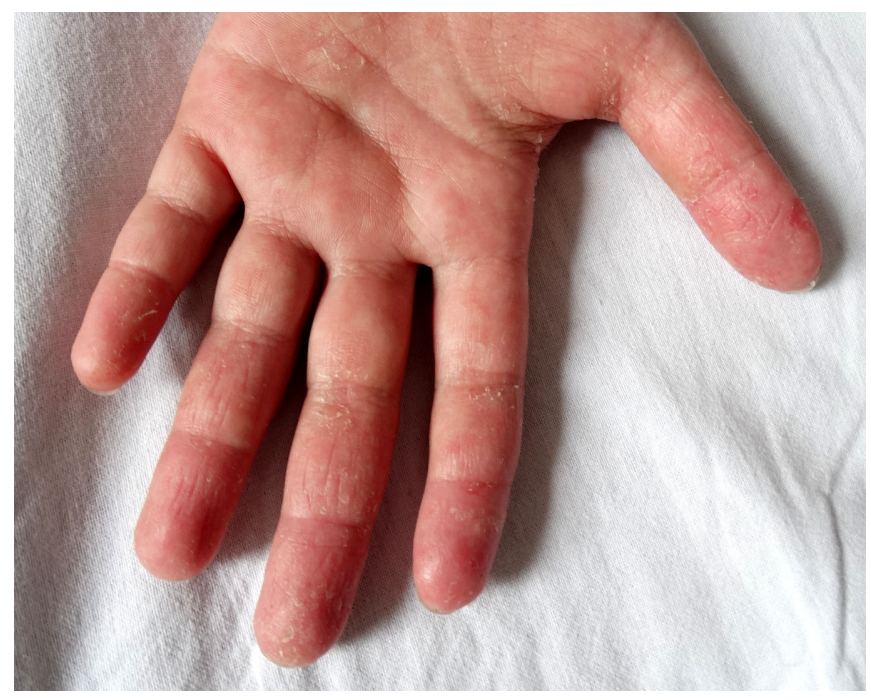

Fig. 2. Nails with striation and lack of eponychium

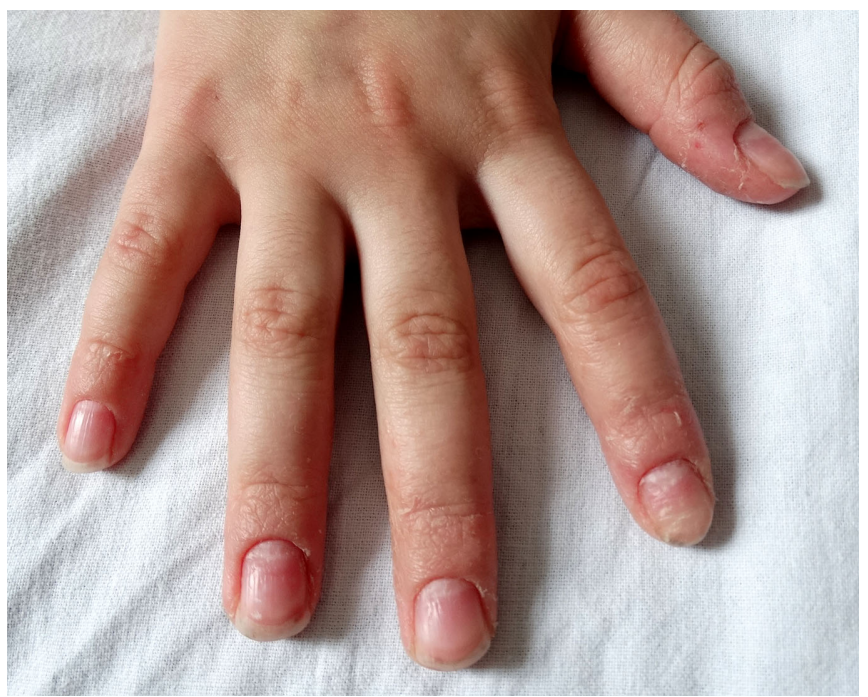


Due to parental disagreement, a skin biopsy was not performed

The epicutaneous testing with allergens from the European Baseline Series S-1000 (Chemotechnique Diagnostics, Welling, Sweden) found positive (+) reactions to N-Isopropyl-N-Phenyl-4-phenylenediamineIPPD) $0,1 \%$ and (++) to 2-Mercaptobenzo-thiazole 2\% (fig.3) The reading was done after 48 and 72 hours.

The topical treatment with Momethasonefuroate cream $0.1 \%$ and emollients lead to complete recovery of the skin changes. The child's parents were advised to stop the patient's contact with products like plasticine and slime.

Fig. 3. Allergic reaction to 2-Mercaptobenzothiazole $(++)$ at 48 hours

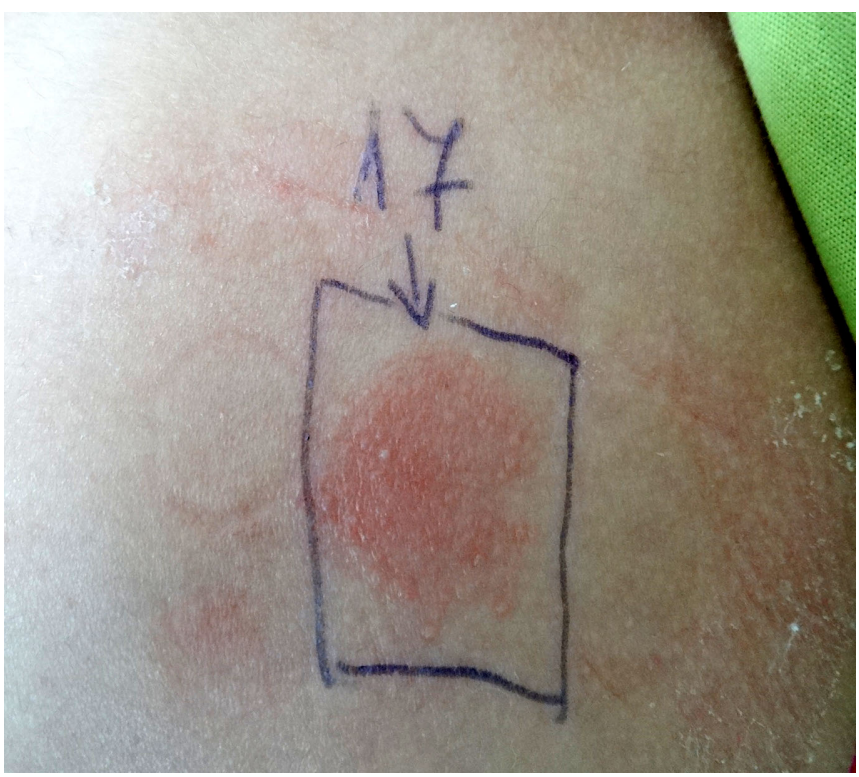

\section{DISCUSSION:}

Rubber is a ubiquitous material with a wide range of different properties, varying because of the different ways of its production. Cases of 1st type allergic reactions are mainly to latex (natural rubber), and cases of 4th type (delayed cell-mediated allergic reaction) are mainly to rubber additives.

Plasticine is a modeling material whose modern variants are made of high molecular weight polyethylene (HMWPE), polyvinyl chloride (PVC), rubber, silicone and other high-tech materials. In the process of rubber production, vulcanization catalysts are added, which provide the elasticity and durability of the final product, and antioxidants, which slow down the aging of the material. 2Mercaptobenzothiazole (catalyst) and IPPD (rubber antioxidant), to which the child in our case is allergic, are a common choice of manufacturers in the production of plasticine [3].

Slime is a highly elastic mixture that attracts children's attention [4]. Slimming is so popular that the most searched "how to" Google query for 2017 is "how to make a slime" [5]. The slime preparation process is based on the chemical bonding of polyvinyl alcohol or polyvinyl acetate (found in liquid adhesives) from boric acid or borax (its salt, which is found in eyewashes, contact lens solutions and liquid detergents). Colorants, brocade, swelling agents are also added [4]. To date, borax has been reported to cause only ICD, but detergents in washing powders and contact lens solutions used as a source of borax contain, in addition to borax, other well-known allergens like the preservatives Methilisothiazolinone and Methilisothiazolinone / Methylchloroisothiazolinone (MI / MCI) [6]. Allergic reactions to slime with a positive patch test to MI / MCI have been reported in the periodical literature $[5,7,8,9,10,11]$. In 2018, Trifunova et al. described for the first time a case of slime dermatitis in Bulgaria [12]. Many slime recipes also include polyvinyl acetate glue with additional ingredienrs, which are proprietary information and not readily available. So in our case, we are not in a position to determine whether slime is contributing to an ICD or to ACD [13].

Epicutaneous testing in children is considered a safe procedure. Carrying it out is sometimes a challenge because of the over-mobility of some children or because of the insufficient surface for attaching allergens to the back. In such cases, patches with stronger adhesion can be used, and the allergens to be tested can be selected. Allergens that are mainly in the work environment can be removed, e.g. Epoxy resin and materials to which the child is actually exposed could be included- topical products, antiseptics, toys and their ingredients [14]. "Individualized" epicutaneous allergy testing may increase the relevance of positive reactions in children [15].

Irritant contact dermatitis accounts for about $80 \%$ of cases of $\mathrm{CD}$, and the remaining $20 \%$ are cases of ACD [16]. Irritant contact dermatitis and ACD are not mutually exclusive and may occur simultaneously in the same patient [17]. Despite the different pathogenesis, ICD and $\mathrm{ACD}$, especially chronic forms, show significant similarity in the clinical picture and histological findings. Clinically, the reactions often appear identical, with erythematous plaques, xerosis, desquamation and lichenification, and clear boundaries indicating the area of contact with the noxa [16]. ICD is sometimes a predisposing factor for the development of allergic contact dermatitis [18]. We suggest that in the case described, the slime acted as an irritant, disrupting the skin barrier, and predisposed to easier sensitization to IPPD and 2-Mercaptobenzothiazole, which are contained in plasticine. Less probably, the slime recipes could also contain glue with additional ingredients like 2-Mercaptobenzothiazole or IPPD (or both).

Therapeutic behaviors in both ICD and ACD include cessation of noxa contact, control of inflammation (via topical corticosteroids), and restoration of the skin barrier by regular application of emollients [13]. 


\section{CONCLUSION}

We present a clinical case of a child with contact dermatitis caused by plasticine with a proven allergy to its ingredients and slime. Irritant and allergic reactions are not mutually exclusive but logically combined disease moments. In such cases of contact dermatitis of the hands, the composition of the patient's toys must be studied in details. It is mandatory to conduct epicutaneous testing with allergens and not to forget the irritation potential of slime. For a favorable therapeutic response, it is appropriate to advise patients to discontinue contact with established substances and to use appropriate barrier agents and emollients.

\section{REFERENCES:}

1. Cashman MW, Reutemann PA, Ehrlich A. Contact dermatitis in the United States: epidemiology, economic impact, and workplace prevention. Dermatol Clin. 2012 Jan; 30(1):87-98, viii. [PubMed] [Crossref]

2. Shah D, Chowdhury MMU. Rubber allergy. Clin Dermatol. 2011 MayJun;29(3):278-86. [PubMed] [Crossref]

3. Belsito D. Rubber. In: Practical Contact Dermatitis: A Handbook for the Practitioner. Guin J. Ed., McGraw-Hill, 1995, p. 373-396.

4. Labadie M, Langrad J, Leroux G, ManelJ, NisseP, Sapori JM, et al. Exposures associated with making or playing with viscoelastic polymer toys known as Slime: a retrospective case series from French Poison Control Centres. Clin Toxicol (Phila). 2020, Jun; 58(6):482-487. [PubMed] [Crossref]

5. Zhang A, Boyd A, Asch S, Warshaw EM. Allergic contact dermatitis to slime: The epidemic of isothiazolinone allergy encompasses school glue. Pediatr Dermatol. 2019 Jan; 36(1):e37-e38. [PubMed] [Crossref]

6. Kondratuk KE, Norton SA. "Slime" Dermatitis, a Fad-Associated Chronic Hand Dermatitis. Pediatr Dermatol. 2019 Jan;36(1):e39-e40. [PubMed] [Crossref]

7. Anderson LE, Treat JR, Brod BA,
Yu JD. "Slime" Contact Dermatitis: Case Report and Review of Relevant Allergens. Pediatr Dermatol. 2019 May; 36(3):335-337. [PubMed] [Crossref]

8. Salman A, Demir G, Apti O. "Slime": A Trending Cause of Isothiazolinone Contact Allergy in Children. Contact Dermatitis. 2019 Jun; 80(6):409-411. [PubMed] [Crossref]

9. Tehrany J, Quenan S, Bugey A, Piletta P. Contact Dermatitis Caused by Homemade "Slime": Report of Two Cases With Chemical Analysis. Contact Dermatitis. 2019, Jun;80(6):407-408. [PubMed] [Crossref]

10. Ducharme O, Labadie M, Briand SM, Milpied B. Allergic Contact Dermatitis in a Child Caused by Isothiazolinones in a "Noise Putty". Contact Dermatitis. 2018 Dec; 79(6):393-394. [PubMed] [Crossref]

11. Aerts O, De Fre C, van Hoof T, GhysK, Ortopelea RA, Lambert J. "Slime": A New Fashion Among Children Causing Severe Hand Dermatitis. Contact Dermatitis. 2018 Dec; 79(6):385-387. [PubMed] [Crossref]

12. Trifunova BK, Demerdjieva ZV, Tsankov NK. Kazandjieva JS. Allergic Contact Dermatitis Caused by Homemade Slime. Serb J Dermatol Venereol. 2018; 10(2):52-56. [Crossref]
13. Gittler JK, Garzon MC, Lauren CT. "Slime" May Not be so Benign: A Cause of Hand Dermatitis. J Pediatr. 2018 Sep;200:288. [PubMed] [Crossref]

14. Johansen JD, Aalto-Korte K, Agner T, Andersen KE, Bircher A, Bruze $\mathrm{M}$, et al. European Society of Contact Dermatitis guideline for diagnostic patch testing - recommendations on best practice. Contact Dermatitis. 2015 Oct;73(4):195-221. [PubMed] [Crossref]

15. Kazandjieva J, Gergovska M, Darlenski R. Contact dermatitis in a child from methlychloroisothiazolinone and methylisothiazolinone in moist wipes. Pediatr Dermatol. 2014 MarApr;31(2):225-7. [PubMed] [Crossref]

16. Nixon R, Mowad C, Marks Jr J. Allergic Contact Dermatitis. In: Dermatology 4th ed. Bolognia J, Schaffer J, Cerroni L, Eds. Elsevier. 2018. p.242261.

17. Warshaw E, Hook K. Dermatitis. In: Clinical Dermatology, 1 st ed. Soutor C, Hourdinsky M, Eds. McGraw-Hill Education. 2013. p. 4759.

18. White J. Irritant Contact Dermatitis. In: Rook's Textbook of Dermatology. Griffits C, Barker J, Bleiker T, Eds., Willey Blackwell. 2016. p. 129.1.

Please cite this article as: TGospodinova K, Yordanova I, Gospodinov D, Kazandjieva J. Contact dermatitis from plasticine and slime in a 9-year-old child. J of IMAB. 2020 Apr-Jun;26(2):3174-3176.

DOI: https://doi.org/10.5272/jimab.2020262.3174

Received: 25/07/2019; Published online: 03/06/2020

\author{
Address for correspondence: \\ Klimentina Gospodinova \\ Department of Dermatology, Venereology and Allergology, Medical University, \\ Pleven, \\ 21 Kiril and Metodii Str., Pleven-5800, Bulgaria. \\ E-mail: klimentina_gospodinova@abv.bg
}

